\title{
Investigation of Toxin Profiles of Methicillin Resistant and Sensitive Staphylococcus aureus Strains Isolated from Various Clinical Specimens
}

\author{
Çeşitli Klinik Örneklerden İzole Edilen Metisiline Dirençli ve Duyarlı Staphylococcus aureus \\ Suşlarının Toksin Profillerinin Araştırılması
}

\author{
Mücella BAYIRLI ${ }^{1}$ \\ (i) 0000-0001-6120-0071 \\ Özkan ASLANTAŞ ${ }^{2}$ \\ (D) 0000-0003-0407-8633 \\ Burçin ÖZER ${ }^{3}$ \\ (D) 0000-0001-8965-9335
}

${ }^{1}$ Hatay Mustafa Kemal University, Graduate School of Health Sciences, Hatay, Turkey

${ }^{2}$ Department of Microbiology, Hatay Mustafa Kemal University Faculty of Veterinary Medicine, Hatay, Turkey

${ }^{3}$ Department of Medical Microbiology, Hatay Mustafa Kemal University Faculty of Medicine, Hatay, Turkey

\begin{abstract}
Aim: This study aimed to investigate the superantigenic (SAg) toxin, exfoliative toxin (ET), hemolysin (HLY), leukotoxin (LUK) genes and accessory gene regulator (agr) types in Staphylococcus aureus isolates from various clinical materials.

Material and Methods: A total of 190 S. aureus isolates were investigated for the presence of toxin genes, mecA gene and $a g r$ types using by polymerase chain reaction (PCR).

Results: mecA gene was detected in $87(45.8 \%)$ isolates. Of the $190 \mathrm{~S}$. aureus isolates examined, $83.7 \%(\mathrm{n}=159)$ were found to be positive for SAg genes. The seg $(41.1 \%)$ was determined to be the most common toxin gene, followed by sei $(38.9 \%)$, selo $(38.9 \%)$, selm $(28.4 \%)$, sea (\%25.8), and tst (18.4\%) genes, respectively. Seventy one different SAg toxin profiles were identified. Type I $v \mathrm{Sa} \beta$ encoding seg, sei, selm, seln and selo was the most common mobile genetic element (MGE), which was detected in 37 isolates $(19.5 \%)$. The hla, hlb, hld, hlg and hlg2 genes were detected in $92.6 \%(\mathrm{n}=176), 1.6 \%(\mathrm{n}=3)$, $98.9 \%(\mathrm{n}=188), 1.1 \%(\mathrm{n}=2)$ and $31.6 \%(\mathrm{n}=60)$ of the isolates, respectively. The $p v l$ gene was detected in $12.6 \%(\mathrm{n}=11)$ of methicillin resistant $S$. aureus (MRSA) and $14.6 \%(\mathrm{n}=15)$ of methicillin sensitive $S$. aureus (MSSA), respectively ( $\mathrm{p}=0.701)$. While none of the isolates carried $l u k \mathrm{M}$ gene, $67 \%(\mathrm{n}=69)$ of MSSA and 69\% $(\mathrm{n}=60)$ of MRSA isolates were found to be positive for lukED gene $(\mathrm{p}=0.519)$.

Conclusion: High occurrence and diversity of toxin genes among S. aureus isolates could be explained by horizontal transmission of toxin genes through MGEs.
\end{abstract}

Keywords: Staphylococcus aureus; methicillin resistance; toxin; gene.

ÖZ

Amaç: $\mathrm{Bu}$ çalışmada çeşitli klinik materyallerden elde edilen Staphylococcus aureus izolatlarında süperantijenik (SAg) toksin, eksfoliatif toksin (ET), hemolizin (HLY) ve lökotoksin (LUK) genleri ve aksesuar gen regülatör (agr) tiplerinin araştırılması amaçland. Gereç ve Yöntemler: Toplam 190 S. aureus izolatında toksin genleri, mecA geni ve agr tipleri polimeraz zincir reaksiyonu (PZR) kullanılarak incelendi.

Bulgular: mecA geni $87(\% 45,8)$ izolatta tespit edildi. İncelenen 190 S. aureus izolatının $\% 83,7$ 'si ( $\mathrm{n}=159) \mathrm{SAg}$ genleri yönünden pozitif bulundu. En yaygin toksin geni seg $(\% 41,1)$ olarak belirlenirken, bunu sirasiyla sei $(\% 38,9)$, selo $(\% 38,9)$, selm $(\% 28,4)$, sea $(\% 25,8)$ ve tst $(\% 18,4)$ genleri izledi. Yetmiş bir farklı SAg toksin profili belirlendi. sei, seg, selm, seln ve selo genlerini taşıyan tip I $v \mathrm{Sa} \beta 37(\% 19,5)$ izolatta tespit edilerek en yaygın mobil genetik element (MGE) olarak belirlendi. $h l a, h l b, h l d, h l g$ ve $h l g 2$ genleri izolatların sirasiyla \%92,6 $(\mathrm{n}=176), \% 1,6(\mathrm{n}=3), \% 98,9(\mathrm{n}=188), \% 1,1(\mathrm{n}=2)$ ve \%31,6'sında $(\mathrm{n}=60)$ tespit edildi. pvl geni sırasıly, metisilin dirençli $S$. aureus (methicillin resistant S. aureus, MRSA) izolatlarının \%12,6'sında $(\mathrm{n}=11)$ ve metisilin duyarlı $S$. aureus (methicillin sensitive S. aureus, MSSA) izolatlarının ise \%14,6'sında $(\mathrm{n}=15)$ saptandı $(\mathrm{p}=0,701)$. İzolatların hiçbiri lukM geni taşımazken, MSSA izolatlarının \%67'si $(\mathrm{n}=69)$ ve MRSA izolatlarının \%69'u ( $\mathrm{n}=60)$ lukED geni için pozitif bulundu $(\mathrm{p}=0,519)$.

Received / Geliş Tarihi : 24.06.2021 Accepted / Kabul Tarihi : 30.09.2021 Available Online / Sonuç: S. aureus izolatları arasında toksin genlerinin yüksek oranda bulunması ve çeşitliliği, toksin genlerinin MGE'ler aracılığıyla horizontal transferi ile açıklanabilir.

Çevrimiçi Yayın Tarihi : 23.11.2021 Anahtar kelimeler: Staphylococcus aureus; metisilin direnci; toksin; gen. 


\section{INTRODUCTION}

Staphylococcus aureus is a versatile pathogen capable of causing a wide range of infections (1). This feature of the agent is due to its genome plasticity of acquiring and incorporating genetic materials from other bacterial species that may have antimicrobial resistance and virulence. Thus, outcome of the infections caused by $S$. aureus strains are closely related with their resistance and virulence properties (2). S. aureus has the ability to produce several virulence factors such as superantigens (SAgs), hemolysins (HLYs), leukotoxins (LUKs), and exfoliative toxins (ETs). Among the exotoxins secreted by S. aureus, staphylococcal enterotoxins (SEs) and toxic shock syndrome toxin-1 (TSST-1) have SAg activity. These toxins are important virulence factors that contribute a variety of pathological conditions, including pneumonia, soft tissue infections, toxic shock syndrome, and infective endocarditis (2,3). Moreover, it has been recently reported that SAgs particularly SEs play a prominent role in the development of asthma of hospitalized patients via induction of $\operatorname{IgE}$ (4). So far, $S$. aureus strains are reported to secrete at least 26 or more types of SEs and staphylococcal enterotoxin-like toxins (SEls). SAgs have the ability to stimulate synthesis of cytokines by binding concurrently to MHC-II complex and V $\beta$ element of TCR (5).

S. aureus is also capable of producing several pore forming toxins (PFTs) that target leukocytes. The $S$. aureus isolates associated with human infections can produce up to five bi-component leukocidins, also known PFTs: Panton-Valentine Leukocidin (PVL), gamma-hemolysin $\mathrm{AB}$ and $\mathrm{CB}$ (HlgAB and HlgCB), Leukocidin ED (LukED), and Leukocidin $\mathrm{AB}$ (LukAB). These toxins protect S. aureus from being killed by phagocytes of the host (6). Exfoliative toxins (ETs), also known as epidermolytic toxins, are highly specific serine proteases secreted by $S$. aureus that are responsible for the clinical manifestation of staphylococcal scalded skin syndrome (SSSS) (7). So far, four types of ET have been reported as exfoliative toxin A/B/C/D (ETA, ETB, ETC, and ETD). Of these, while ETA and ETB were the most common types in humans, ETC was only detected in isolates from horse infections. In 2002, ETD was only defined in clinical $S$. aureus isolates in humans (8).

Among the wide variety of Staphylococcal cytolytic exotoxins produced, HLYs are the most prominent and well-characterized ones which play an important role in the pathogenesis of staphylococcal infections. HLYs $\alpha, \beta$, $\gamma$, and $\delta$ cause pore formation on various cell membranes including immune cells that lead leakage of cellular molecules and metabolites outside of the cell in favor of the survival of the pathogen and progression of the disease (9).

The accessory gene regulator (agr) system is one of the main regulatory and control factors involved in the control of pathogenesis of $S$. aureus by regulating virulence factors, biofilm formation and resistance. S. aureus is divided into 4 different $a g r$ groups (agr I, agr II, $a g r$ III, and $a g r$ IV) based on mutations and polymorphisms of $\operatorname{agrC}$ and $a g r \mathrm{D}$ genes (10). It was stated that prevalence of agr types vary according to geographical areas (11). Moreover, a link between agr types and certain diseases manifestations and clinical outcome has been reported (12).
Jarraud et al. (13) suggested that agr type III is more prevalent in TSST-1 producing isolates and agr type IV is more prevalent in ET producing isolates.

The main aim of the current study was to investigate the prevalence of SAg (SE, TSST-1), ET, HLY, and LUK genes in methicillin resistant $S$. aureus (MRSA) and methicillin sensitive $S$. aureus (MSSA) isolates.

\section{MATERIAL AND METHODS \\ Ethical Considerations}

This study was approved by the non-interventional clinical researches ethics committee of Hatay Mustafa Kemal University (05.09.2019, 14/2019).

\section{S. aureus Isolates}

All S. aureus strains isolated from different clinical materials submitted to the Microbiology Laboratory of the Hatay Mustafa Kemal University Hospital from January to September 2020 were included in the study. Suspected colonies were identified by hemolysis properties, Gram staining, catalase, coagulase and other biochemical tests (14). Identification of the strains and antibiotic susceptibilities of these isolates were determined with the Vitek 2 compact system (bioMe'rieux, France) and evaluated according to the breakpoints of the European Committee for Antimicrobial Susceptibility Tests (EUCAST) (15). They were confirmed by polymerase chain reaction (PCR) using primers specific to the nuc gene (16).

\section{DNA Isolation}

DNA isolation from the isolates was performed using a commercial extraction kit (InstaGeneTM Matrix, Bio-Rad, France). The resulting template DNAs were stored at $-20{ }^{\circ} \mathrm{C}$ until use.

\section{Detection of mecA Gene}

The mecA gene in phenotypically methicillin resistant isolates were investigated as previously described by Choi et al. (17).

\section{Detection of Toxin Genes by PCR}

The genes encoding SEs (sea, seb, sec, sed, see, seg, seh, sei, selj, selk, sell, selm, seln, selo, selp, selq, and selr), TSST-1 (tst), ET (eta, etb), leukocidins ( $p v l, l u k \mathrm{ED}$, and $l u k \mathrm{M})$ and HLYs (hla, hlb, hld, hlg) were examined as previously described by Omoe et al. (18), Jarraud et al. (13), Mehrotra et al. (19) and Lina et al. (20), respectively.

\section{agr Typing}

Determination of the agr types of $S$. aureus isolates was performed using multiplex PCR method as previously described by Gilot et al. (21).

\section{Statistical Analysis}

The statistical analyses was carried out using SPSS v.16 (SPSS Inc., Chicago, IL, USA). The frequencies of the variables was presented as numbers and percentages. The Pearson chi-square test, Fisher's exact test, and Fisher-Freeman-Halton test were used to compare categorical variables where appropriate. $\mathrm{p}<0.05$ was considered as statistically significant.

\section{RESULTS}

\section{PCR results for mecA}

All S. aureus isolates were positive for nuc gene. Based on PCR amplification of mecA gene, 87 isolates were identified as MRSA and 103 as MSSA. The distribution of 
MRSA isolates according to the clinical materials is given in Table 1. No statistically significant difference was found in terms of the type of clinical materials from which the MRSA strains were isolated $(\mathrm{p}=0.577)$.

Distribution of SAg and ET Genes in MSSA and MRSA Isolates

Distribution of SAg toxins and ET genes detected in MSSA and MRSA isolates is given in Table 2. Thirty-one $(16.3 \%)$ isolates did not have any SAg's toxin genes examined. The most common SE genes were seg (41.1\%), sei $(38.9 \%)$, selo $(38.9 \%)$, selm $(28.4 \%)$, and sea $(25.8 \%)$. While eta was observed in $9(4.7 \%)$ isolates (6 MSSA and 3 MRSA isolates), etb was carried by seven MSSA and one MRSA isolates. SAg toxin genotypes and their relationship with MGEs are shown in Table 3.

\section{Distribution of Hemolysin Genes}

Nearly all isolates at least carried one of the HLY genes examined, except one MSSA isolate. There was no statistically significant difference between MSSA and MRSA isolates in terms of distribution of HLY genes $(p=0.309)$. The distribution of HLY genes is given in Table 4.

\section{Distribution of Leukocidin Genes}

While all isolates were negative for $l u k \mathrm{M}$ gene, the $l u k \mathrm{ED}$ gene was detected in $67 \%(n=69)$ of the MSSA isolates and in $69 \%(n=60)$ of the MRSA isolates $(p=0.519)$. As seen in Table 5, the $p v l$ gene was detected in $14.6 \%(n=15)$ of the MSSA isolates and in $12.6 \%(n=11)$ of the MRSA isolates $(\mathrm{p}=0.701)$.

\section{Distribution of agr Types}

As seen in Table 6, agr type I (56.8\%) was the most common type among the isolates, followed by agr type III (22.1\%) and $a g r$ type II (16.8\%). Distribution of agr types between MSSA and MRSA isolates was statistically significant $(\mathrm{p}=0.001)$.

\section{DISCUSSION}

The pathogenicity of $S$. aureus has been attributed to their ability to evade both innate and acquired immune mechanisms of the host (22). Apart from virulence repertoire of $S$. aureus, which plays an important role in the pathogenesis, the emergence and increasing prevalence of MRSA in healthcare institutions is one of the most important challenges encountered in the treatment of $S$. aureus infections. Methicillin resistance is one of important resistance mechanisms observed in S. aureus isolates. Based on mecA PCR results, a higher prevalence $(55.8 \%)$ of MRSA was detected. In Iran, Motamedifar et al. (23) reported a similar prevalence rate $(57.7 \%)$. In previous studies carried out in Turkey, prevalence of MRSA was reported as $17.9 \%$ by Özel et al. (24), $22.9 \%$ by Tanrıverdi Çaycı et al. (25), 24\% by Arıcı and Aksaray (26), 12.5\% in hospital acquired (HA)-S. aureus isolates and $43 \%$ in community acquired (CA)- $S$. aureus isolates by Duman et al. (27), $30.8 \%$ by Kılıç et al. (28), and $44 \%$ by Şahin et al. (29). In contrast, Karahan et al. (30) reported higher a prevalence rate in HA-S. aureus isolates $(83.9 \%)$ and CA-S. aureus isolates $(91.9 \%)$. Compared to most of the MRSA rates mentioned above, the high rate of MRSA detected in this study can be explained by the nosocomial infections or widespread use of beta-lactams in the region. It has been suggested that $S$. aureus isolates expressing PVL cause severe skin and soft tissue infections, necrotizing fasciitis and life-threatening infections such as
Table 1. The distribution of $S$. aureus isolates according to the clinical materials

\begin{tabular}{lcccc}
\hline Clinical Material & MSSA & MRSA & p & Total \\
\hline Throat swab & $2(1.9)$ & $2(2.3)$ & & $4(2.1)$ \\
Nasal Swab & $4(3.9)$ & $8(9.2)$ & & $12(6.3)$ \\
Wound & $27(26.2)$ & $19(21.8)$ & $46(24.2)$ \\
Blood & $30(29.1)$ & $27(31.0)$ & $57(30.0)$ \\
Urine & $32(31.1)$ & $21(24.1)$ & 0.609 & $53(27.9)$ \\
Sputum & $3(2.9)$ & $4(4.6)$ & & $7(3.7)$ \\
Cerebrospinal fluid & $2(1.9)$ & $5(5.7)$ & $7(3.7)$ \\
Vaginal Discharge & $2(1.9)$ & $1(1.1)$ & $3(1.6)$ \\
Tracheal Aspirate & $1(1.0)$ & $0(0.0)$ & $1(0.5)$ \\
\hline Total & $\mathbf{1 0 3}$ & $\mathbf{8 7}$ & $\mathbf{1 9 0}$ \\
\hline MSSA: methicillin sensitive S. aureus, MRSA: methicillin resistant S. aureus
\end{tabular}

MSSA: methicillin sensitive $S$. aureus, MRSA: methicillin resistant $S$. aureus

Table 2. Distribution of SAg toxin and ET genes detected in MSSA and MRSA isolates

\begin{tabular}{lcccc}
\hline SAg & MSSA $(\mathbf{n = 1 0 3})$ & MRSA $(\mathbf{n = 8 7})$ & $\mathbf{p}$ & Total \\
\hline sea & $25(24.3)$ & $24(27.6)$ & 0.603 & $49(25.8)$ \\
seb & $5(4.9)$ & $2(2.3)$ & 0.456 & $7(3.7)$ \\
sec & $3(2.9)$ & $1(1.1)$ & 0.626 & $4(2.1)$ \\
sed & $9(8.7)$ & $6(6.9)$ & 0.639 & $15(7.9)$ \\
selq & $13(12.6)$ & $13(14.9)$ & 0.643 & $26(13.7)$ \\
selo & $40(38.8)$ & $34(39.1)$ & 0,972 & $74(38.9)$ \\
selm & $32(31.1)$ & $22(25.3)$ & 0,378 & $54(28.4)$ \\
selr & $10(9.7)$ & $6(6.9)$ & 0.487 & $16(8.4)$ \\
selk & $16(15.5)$ & $10(11.5)$ & 0.420 & $26(13.7)$ \\
seln & $17(16.5)$ & $10(11.5)$ & 0.324 & $27(14.2)$ \\
sell & $6(5.8)$ & $6(6.9)$ & 0.762 & $12(6.3)$ \\
seg & $48(46.6)$ & $30(34.5)$ & 0.091 & $78(41.1)$ \\
sei & $44(42.7)$ & $30(34.5)$ & 0.246 & $74(38.9)$ \\
seh & $6(5.8)$ & $20(23)$ & $\mathbf{0 . 0 0 1}$ & $26(13.7)$ \\
selj & $8(7.8)$ & $6(6.9)$ & 0.819 & $14(7.4)$ \\
selp & $5(4.9)$ & $4(4.6)$ & 0.999 & $9(4.7)$ \\
tst & $14(13.6)$ & $21(24.1)$ & 0.062 & $35(18.4)$ \\
eta & $6(5.8)$ & $3(3.4)$ & 0.512 & $9(4.7)$ \\
etb & $7(6.8)$ & $1(1.1)$ & 0.072 & $8(4.2)$ \\
\hline SAg: superative & &
\end{tabular}

SAg: superantigen, ET: exfoliative toxin, MSSA: methicillin sensitive $S$, aureus, MRSA: methicillin resistant $S$. aureus

hemorrhagic pneumonia (31). In previous studies conducted in Turkey, it was reported that the prevalence rates of $p v l$ gene varied between $1.9-5.4 \%$ in MSSA isolates and $1.5-9.5 \%$ in MRSA isolates $(28,30,32)$. Another study conducted by Duman et al. (27), showed that $p v l$ gene was detected in $15 \%(6 / 88)$ of the CA-S. aureus isolates and in $3 \%(6 / 177)$ of the HA- S. aureus isolates. In this study, eta and $e t b$ genes were detected in $4.7 \%$ and $4.2 \%$ of the isolates, respectively. Although isolation rates were higher in MSSA isolates $(1.7 \%$ for eta and $6.7 \%$ for etb) compared to MRSA isolates $(2.9 \%$ for eta and $1.1 \%$ for $e t b)$, this was not statistically significant. In previous studies, absence or low prevalence rates of ET genes has been reported. Xie et al. (33) reported the prevalence of eta, etb and etd genes in 108 clinical $S$. aureus isolates as $1.9 \%, 0 \%$ and $8.3 \%$, respectively. Jiménez et al. (34) could 
Table 3. SAg toxin genotypes identified in MSSA and MRSA isolates and their relationship with MGE

\begin{tabular}{|c|c|c|c|c|}
\hline SAg Toxin & MSSA & MRSA & Total & Possible MGE \\
\hline sea & 5 & 4 & 9 & $\varphi \mathrm{Sa} 3 \mathrm{mu}$ \\
\hline sea, tst & - & 1 & 1 & $\varphi \mathrm{Sa} 3 \mathrm{mu}+t s t$ \\
\hline sea, selq & - & 1 & 1 & $\varphi \mathrm{Sa} 3 \mathrm{mu}+\mathrm{sel} q$ \\
\hline sea, sed & 1 & 1 & 2 & $\varphi \mathrm{Sa} 3 \mathrm{mu}+\mathrm{sed}$ \\
\hline sea, selo & - & 1 & 1 & $\varphi \mathrm{Sa} 3 \mathrm{mu}+$ selo \\
\hline sea, seg, sei & 2 & 1 & 3 & $\varphi \mathrm{Sa} 3 \mathrm{mu}+\mathrm{seg}+\mathrm{sei}$ \\
\hline sea, selk, selq & 2 & - & 2 & $\varphi \mathrm{Sa} 3 \mathrm{mw}+$ selk + selq \\
\hline sea, selm, selo & 1 & 1 & 2 & $\varphi \mathrm{Sa} 3 \mathrm{mu}+$ selm + selo \\
\hline sea, seg, selm, selo & 2 & - & 2 & $\varphi \mathrm{Sa} 3 \mathrm{mu}+$ seg + selm+selo \\
\hline sea, seg, sei, tst & 1 & - & 1 & $\varphi \mathrm{Sa} 3 \mathrm{mu}+\mathrm{seg}+\mathrm{sei}+t s t$ \\
\hline sea, selm, selo, selr & - & 1 & 1 & $\varphi \mathrm{Sa} 3 \mathrm{mu}+$ selm + selo + selr \\
\hline sea, selo, tst & - & 1 & 1 & $\varphi \mathrm{Sa} 3 \mathrm{mu}+$ selo $+t s t$ \\
\hline sea, seb, seg, sei, seh, tst & 1 & - & 1 & $\varphi \mathrm{Sa} 3 \mathrm{mu}+s e b+s e g+s e i+s e h+t s t$ \\
\hline sea, seg, sei, selm, seln, selo & 1 & 1 & 2 & $\varphi S a 3 m u$, Tip I vSa $\beta$ \\
\hline sea, seg, sei, seh, tst & 2 & - & 2 & $\varphi \mathrm{Sa} 3 \mathrm{mu}+\operatorname{seg}+\operatorname{sei}+\mathrm{seh}+t s t$ \\
\hline sea, seg, sei, selm, seln, selo & 1 & - & 1 & $\varphi S a 3 m u$, Tip I vSa $\beta$ \\
\hline sea, sed, selj, seln, selk, selr & - & 1 & 1 & $\varphi \mathrm{Sa} 3 \mathrm{mu}, \mathrm{pIB} 485$ \\
\hline sea, sec, seg, sei, sell, selm, selo & - & 1 & 1 & $\varphi \mathrm{Sa} 3 \mathrm{mu}$, Tip II $v \mathrm{Sa} 3$, Tip I vSa $\beta$ \\
\hline sea, seg, sei, sell, selm, selo, selr, tst & - & 1 & 1 & $\varphi \mathrm{Sa} 3 \mathrm{mu}, \mathrm{Tip} \mathrm{I} v \mathrm{Sa} \beta$ \\
\hline sea, seg, sei, selm, seln, selo, tst & 1 & - & 1 & $\varphi \mathrm{Sa} 3 \mathrm{mu}$, Tip I $v \mathrm{Sa} \beta+t s t$ \\
\hline sea, sed, selj, selk, selq, selr & 4 & - & 4 & $\varphi \mathrm{Sa} 3 \mathrm{mw}, \mathrm{pIB} 485$ \\
\hline sea, seh, selk, selq & - & 2 & 2 & $\varphi \mathrm{Sa} 3 \mathrm{mw}+\mathrm{seh}$ \\
\hline sea, seg, sei, selk, selq, tst & - & 2 & 2 & $\varphi \mathrm{Sa} 3 \mathrm{mw}+s e g+s e i+t s t$ \\
\hline sea, seg, sei, selk, selq & - & 2 & 2 & $\varphi \mathrm{Sa} 3 \mathrm{mw}+$ seg + sei \\
\hline$s e b$ & 3 & - & 3 & $\mathrm{ND}$ \\
\hline seb, seg, sei, selk, selm, selo, selq, tst & 1 & - & 1 & Tip I vSaß, vSal (SaPI3)+tst \\
\hline seb, seg, sei, selk, selq & - & 1 & 1 & $v \mathrm{Sa} 1(\mathrm{SaPI})+s e g+s e i$ \\
\hline sec, seg, sei, selm, seln, selo, selr & 2 & - & 2 & Tip I vSa $\beta+s e c+s e l r$ \\
\hline sec, seg, sei, sell, selm, selo, selp & 1 & - & 1 & Tip II vSa3, Tip I vSaß, $\varphi$ Sa3n \\
\hline sed, selj, selr & 1 & - & 1 & pIB485 \\
\hline sed, seg, sei, seln, tst & - & 2 & 2 & ND \\
\hline sed, seg, sei, selm, seln, selo & 2 & - & 2 & Tip I $v S a \beta+s e d$ \\
\hline sed, seg, sei, selm, seln, selo, tst & - & 1 & 1 & Tip I vSa + sed+tst \\
\hline sed, seg, sei, selj, selm, selo, selr & - & 1 & 1 & Tip I vSaß, pIB485 \\
\hline sed, seg, sei, selk, seln & 1 & - & 1 & $\mathrm{ND}$ \\
\hline sed, selm, seln, selo, tst & - & 1 & 1 & ND \\
\hline seg, sei & 4 & 3 & 7 & ND \\
\hline seg, sei, tst & 4 & - & 4 & ND \\
\hline seg, sei, selk, selr & 2 & - & 2 & ND \\
\hline seg, sei, selm, seln, selo & 3 & 1 & 4 & Tip I $v S a \beta$ \\
\hline seg, sei, selj, selm, seln, selo, tst & 2 & 1 & 3 & Tip I vSa $\beta+$ selj+tst \\
\hline seg, sei, selj, selm, selq, selo, tst & - & 2 & 2 & Tip I vSa $\beta+$ selj+tst \\
\hline seg, sei, selm, selo, selq & - & 1 & 1 & Tip I vSa $\beta$ \\
\hline seg, sei, selo, selm & 9 & 3 & 12 & Tip I $v S a \beta$ \\
\hline seg, sei, selp, seln, selk & 1 & - & 1 & $\varphi \mathrm{Sa} 3 \mathrm{n}$ \\
\hline seg, sei, seh, selm, selo & 1 & - & 1 & Tip I $v S a \beta$ \\
\hline seg, sei, selm, seln, selo, tst & 1 & - & 1 & Tip I vSa $\beta$ \\
\hline seg, sei, sell, selm, selo, selr, tst & - & 1 & 1 & Tip I $v$ Sa $\beta+$ sell + selr $+t s t$ \\
\hline seg, sei, selp, sell, selm, selr, selo & - & 1 & 1 & Tip I $v S a \beta, \varphi S a 3 n$ \\
\hline seg, sei, selk, seln, tst & - & 2 & 2 & ND \\
\hline seg, sei, sell, selm, selo, selr & 1 & 1 & 2 & Tip I $v \mathrm{Sa} \beta$ \\
\hline seg, sei, selj, selm, selo, tst & 1 & 2 & 3 & Tip I $v \mathrm{Sa} \beta+\operatorname{selj}+t s t$ \\
\hline seg, sell, selm, selo, selr & 1 & - & 1 & $\mathrm{ND}$ \\
\hline seh & 1 & 10 & 11 & ND \\
\hline seh, sell & - & 2 & 2 & ND \\
\hline seh, selm, selo & - & 2 & 2 & ND \\
\hline seh, selq, tst & - & 1 & 1 & ND \\
\hline seh, selo, selk, tst & - & 1 & 1 & ND \\
\hline seh, selm, selo, tst & - & 1 & 1 & ND \\
\hline selo & 2 & 2 & 4 & ND \\
\hline selm, selo & 1 & 1 & 2 & ND \\
\hline selm, selo, tst & 2 & 1 & 3 & ND \\
\hline selp & 1 & 1 & 2 & $\varphi \mathrm{Sa} 3 \mathrm{n}$ \\
\hline selp, selq & - & 1 & 1 & $\varphi \mathrm{Sa} 3 \mathrm{n}$, selq \\
\hline selq & 1 & - & 1 & ND \\
\hline selq, selk & 3 & - & 3 & ND \\
\hline selm, selo, selq & 2 & 0 & 2 & ND \\
\hline selk, selm, selo, selq, tst & - & 1 & 1 & ND \\
\hline selk, selq & 3 & - & 3 & ND \\
\hline tst & 1 & - & 1 & ND \\
\hline sell & 1 & - & 1 & ND \\
\hline Negative & 17 & 14 & 31 & \\
\hline
\end{tabular}

SAg: superantigen, MSSA: methicillin sensitive $S$. aureus, MRSA
was not established between suspected MGE and toxin profile 
Table 4. Hemolysin gene combinations determined in MSSA and MRSA isolates

\begin{tabular}{|c|c|c|c|c|}
\hline Hemolysin & $\begin{array}{c}\text { MSSA } \\
(n=103)\end{array}$ & $\begin{array}{l}\text { MRSA } \\
(n=87)\end{array}$ & $\mathbf{p}$ & $\begin{array}{c}\begin{array}{c}\text { Total } \\
(\mathbf{n}=190)\end{array} \\
\end{array}$ \\
\hline hly $\mathrm{A}$ & $1(1.0)$ & $0(0.0)$ & & $1(0.5)$ \\
\hline$h l y \mathrm{D}$ & $8(7.8)$ & $4(4.6)$ & & $12(6.3)$ \\
\hline$h l y \mathrm{~A}-h l y \mathrm{D}$ & $59(57.3)$ & $52(59.8)$ & & $111(58.4)$ \\
\hline hlyA-hlyD-hlyG2 & $32(31.1)$ & $27(31.0)$ & & $59(31.1)$ \\
\hline$h l y \mathrm{~A}-h l y \mathrm{D}-h l y \mathrm{~B}$ & $0(0.0)$ & $2(2.3)$ & 0.309 & $2(1.1)$ \\
\hline$h l y \mathrm{~A}-h l y \mathrm{D}-h l y \mathrm{G}$ & $2(1.9)$ & $0(0.0)$ & & $2(1.1)$ \\
\hline$h l y \mathrm{D}-h l y \mathrm{G} 2$ & $0(0.0)$ & $1(1.1)$ & & $1(0.5)$ \\
\hline$h l y \mathrm{~A}-h l y \mathrm{D}-h l y \mathrm{~B}-h l y \mathrm{G} 2$ & $1(1.0)$ & $0(0.0)$ & & $1(0.5)$ \\
\hline Negative & $0(0.0)$ & $1(1.1)$ & & $1(0.5)$ \\
\hline
\end{tabular}

Table 5. Distribution of $p v l$ gene among the MSSA and MRSA isolates

\begin{tabular}{lcccc}
\hline $\boldsymbol{p} \boldsymbol{v} \boldsymbol{l}$ & $\begin{array}{c}\text { MSSA } \\
(\mathbf{n}=\mathbf{1 0 3})\end{array}$ & $\begin{array}{c}\text { MRSA } \\
(\mathbf{n}=\mathbf{8 7})\end{array}$ & $\mathbf{p}$ & $\begin{array}{c}\text { Total } \\
(\mathbf{n}=\mathbf{1 9 0})\end{array}$ \\
\hline Negative & $88(85.4)$ & $76(87.4)$ & 0.701 & $164(86.3)$ \\
Positive & $15(14.6)$ & $11(12.6)$ & & $26(13.7)$ \\
\hline MSSA: methicillin sensitive $S$. aureus, MRSA: methicillin resistant S. aureus
\end{tabular}

Table 6. Distribution of agr types according to MSSA and MRSA isolates

\begin{tabular}{|c|c|c|c|c|}
\hline agr Туре & $\begin{array}{c}\text { MSSA } \\
(n=103)\end{array}$ & $\begin{array}{l}\text { MRSA } \\
(\mathrm{n}=87)\end{array}$ & $\mathbf{p}$ & $\begin{array}{c}\text { Total } \\
(\mathrm{n}=190)\end{array}$ \\
\hline agr type I & $53(51.5)$ & $55(63.2)$ & \multirow{6}{*}{0.001} & $108(56.8)$ \\
\hline agr type II* & $27(26.2)$ & $5(5.7)$ & & $32(16.8)$ \\
\hline agr type III* & $17(16.5)$ & $25(28.7)$ & & $42(22.1)$ \\
\hline$a g r$ type I-II & $4(3.9)$ & $1(1.1)$ & & $5(2.6)$ \\
\hline agr type I-III & $1(1.0)$ & $1(1.1)$ & & $2(1.1)$ \\
\hline agr type II-III & $1(1.0)$ & $0(0.0)$ & & $1(0.5)$ \\
\hline
\end{tabular}

agr: accessory gene regulator, MSSA: methicillin sensitive $S$. aureus, MRSA: methicillin resistant $S$. aureus, ${ }^{*}$ : statistically significant differences for these two agr types

not detect the eta and etb genes in MSSA (n=30) isolates, but detected the eta gene in only one the MRSA $(n=30)$ isolate. de Souza et al. (35) did not find the eta and etb genes in any of MRSA isolates, but detected the eta gene in only $2.3 \%(3 / 130)$ of the MSSA isolates. Similarly, Nhan et al. (36) reported a low prevalence rate for eta (1/1186) among clinical $S$. aureus isolates. In contrast, high prevalence rates of ET genes among $S$. aureus isolates was reported by Demir et al. (37), who found that $20 \%(n=24)$ of the isolates were positive for the $e t a$ and $e t b$ genes.

It has been noted that the prevalence of tst gene among MRSA isolates has increased in recent years. Similarly, in this study, the frequency of $t s t$ gene was found to be higher in MRSA isolates in comparison to MSSA isolates (24.1\% vs $13.6 \%, \mathrm{p}=0.062$ ). $\mathrm{Hu}$ et al. (38) reported higher prevalence rate and found the $t s t$ gene in $85.6 \%(101 / 118)$ of MRSA isolates and 10\% (14/140) of MSSA isolates. However, a contradictory result was reported by Motamedifar et al. (23), who detected the tst gene in $18.1 \%$ (36/199) of MSSA isolates and $11.6 \%$ (17/146) of MRSA isolates.

The presence of SE genes among MRSA and MSSA isolates was found to be abundant and diverse as $83.7 \%$ $(n=159)$ of the isolates (Table 2, Table 3). Xie et al. (33) found that $85.2 \%(92 / 108)$ of the $S$. aureus isolates were positive for SE genes and sea $(44.4 \%)$, selk $(42.6 \%)$ and selq $(40.7 \%)$ as the most common SE genes. The researchers also reported sea-selk-selq $(41.3 \%, 38 / 92)$ as the most common SE combination. In another study, Demir et al. (37) detected that 69 of $120(57.5 \%)$ S. aureus isolates had one or more SE genes, with a dominance of seg and sei (49/120, 40.8\%) genes. Hu et al. (38) investigated MRSA and MSSA isolates for classical and newly described SE genes, and found that 78\% (92/118) of the MRSA isolates and $75.7 \%(89 / 140)$ of MSSA isolates were positive for SE genes. The authors also noted that sea (45\%) and sec (39\%) genes were as the most common SE genes and sec-seg-sei-sell-selm-seln-selo-tst as the dominant genotype $(52 / 118,44.1 \%)$ among MRSA isolates; on the other hand, sea (42\%), selk (38\%) and sec $(35 \%)$ genes were as the most common SE genes and seg-sei-sell-selm-seln-selo as dominant genotype (18/140, $12.9 \%$ ) among MSSA isolates. Tekeli et al. (39) investigated 100 MRSA isolates from the blood cultures of hospitalized patients for the SE genes, and detected the SE genes in $86 \%$ of the isolates and distribution of SE as sea (77\%), sea-seg (4\%), sea-seg-sec (1\%) and seg-sei (2\%). Of the exotoxins synthesized by $S$. aureus isolates, HLYs are among the toxins that play important roles in the pathogenesis of staphylococcal infections. These toxins exert a lethal effect on different host cell populations, including immune cells, and have the ability to help the spread of bacteria within the host body (40). Previous studies have revealed that HLY genes are widely distributed among MSSA and MRSA isolates. In this study, nearly all isolates were found to be positive for one or more investigated HLY genes. Similar observations have also been reported in previous studies (41-44).

$S$. aureus is one of notorious bacteria that has the ability to produce PFTs targeting leukocytes (6). The lukED gene, located in mobile staphylococcal pathogenicity island called vSA $\beta$ (45), was detected in $67.9 \%$ (129/190) of the isolates, of which $69(67 \%)$ were MSSA and 60 (69\%) were MRSA. However, none of the isolates was positive for lukM gene. Comparable prevalence rate was also reported by Havaei et al. (46), who detected $l u k E D$ in $73.8 \%(110 / 149)$ of the isolates. On the other hand, He et al. (47) detected lukED in $81.4 \%$ (144/177) of the isolates, but $l u k \mathrm{M}$ was not detectable in any isolates.

In this study, most of the isolates $(56.8 \%)$ belonged to $a g r$ type I, followed by agr type III (22.1\%) and agr type II (16.8\%), respectively. The agr type IV was not detected in any of the isolates. Similarly, Peerayeh et al. (48) reported that most of the $S$. aureus isolates belonged to agr type I (55.1\%), followed by agr type II (16.9\%), agr type III (16.5\%) and agr type IV (9.4\%), respectively. Similar observations were also reported by Shopsin et al. (49) and van Leeuwen et al. (50), who reported that $42.1 \%$ and $71 \%$ of the isolates were belonged to agr type I, respectively. In contrast, Tekeli et al. (39) reported a higher rate (91\%) of agr type I in 100 MRSA strains isolated from blood cultures. In this study, the authors did not detect agr type IV among the isolates. The absence of $a g r$ type IV has also been reported in previous studies (49-52). The differences observed in the distribution of agr types among $S$. aureus isolates could be explained by ecological and geographical 
differences. Interestingly, some isolates carried more than one agr type in this study. A similar observation was also reported by Yoon et al. (53), who detected co-presence of agr type I-II and agr type I-III in $4.4 \%$ and $0.6 \%$ of the isolates, respectively. $\mathrm{Ji}$ et al. (54) explained this phenomenon with significant sequence changes in the domain encoding the $\operatorname{agrD}$ signal peptide.

Jarraud et al. (13) reported that there is a relationship between agr groups and infection types, and suggested that the strains belong to $a g r$ type IV are mostly associated with generalized exfoliative and suppurative infections, whereas the strains belonged to $a g r$ type I and II are associated with endocarditis cases. Moreover, Ji et al. (54) reported that TSST-1 producing isolates were associated with agr type III. In this study, ET and TSST-1 producing isolates were mainly found to belong to $a g r$ types I and II. The SAg toxin genes have been reported to be largely associated with MGE, such as pathogenicity islands, prophages, SCCmec element and plasmids (55). Seventy one SAg toxin gene profile determined in the study suggested possible presence of MGEs encoding SAg toxins. Type I vSa $\beta$ (in $24 \mathrm{MSSA}$ and $13 \mathrm{MRSA}$ ) and $\varphi \mathrm{Sa} 3 \mathrm{mu}$ (in $18 \mathrm{MSSA}$ and 16 MRSA) were identified as the most common MGEs, followed by $\varphi \mathrm{Sa} 3 \mathrm{mw}$ (in 4 MSSA and 7 MRSA), $\varphi S a 3 n$ (in 3 MSSA and 3 MRSA), pIB485 (in 5 MSSA and 1 MRSA) and Type II $v$ Sa3 (in 1 MSSA and 1 MRSA). Of the determined MGEs, $\varphi S a 3 m u$ encodes sea; type I vSaß seg, sei, selm, seln and selo; type II vSa3 sec, sell; vSa1 (SaPI3) seb, selk, selq; type I vSa4 sec, sell, tst; $\varphi$ Sa3mw sea, selk, selq; $\varphi$ Sa3n selp; pIB485 sed, selj, selr and SaPI1 seb, selk, selq genes. In this study, MGEs were detected at a higher frequency in MRSA isolates. Similarly, while $\mathrm{Hu}$ et al. (37) found type I $v \mathrm{Sa} \beta$ and type I $v \mathrm{Sa} 4$ in $83.1 \%$ and $77.1 \%$ of the MRSA isolates, and also these MGEs were found in $25 \%$ and $2.1 \%$ of MSSA isolates.

The clinical outcome of $S$. aureus infections is influenced not only by the presence of antimicrobial resistance, but also virulence factors. The acquisition of antibiotic resistance genes in $S$. aureus isolates has been reported to cause changes in the expression of virulence genes depending on the fitness cost associated with the expression of resistance genes leading to a decrease in toxin expression (34). Therefore, it is not surprising in this respect that virulence genes were detected at a higher rate in MSSA isolates than MRSA isolates.

In this study, we aimed to search only the mecA gene, not the mec $\mathrm{C}$ gene among the fenotipitic resistant isolates. Therefore, this situation can be considered as a limitation of the study.

\section{CONCLUSION}

The results of this study showed that there is a high genetic diversity in terms of toxin genes among the clinical $S$. aureus isolates, and that the presence and combination of toxin genes are not limited to MSSA or MRSA, indicating frequent transfer of toxin gene-containing MGEs among $S$. aureus populations. In addition, the novel SE gene combinations observed herein suggest the existence of variants or novel types of MGEs. Comparative molecular studies involving large MSSA and MRSA populations are needed to understand how native MSSA and MRSA populations arise and interact.
Ethics Committee Approval: The study was approved by the Ethics Committee of Hatay Mustafa Kemal University (05.09.2019, 14).

Conflict of Interest: None declared by the authors.

Financial Disclosure: This project was supported by the Scientific Research Projects Coordination Unit at Hatay Mustafa Kemal University (Project Number: 19.YL.051)

Acknowledgements: This study was derived from the MSc dissertation of the first author, Mücella BAYIRLI.

Author Contributions: Idea/Concept: MB, ÖA, BÖ; Design: MB; Data Collection/Processing: MB; Analysis/Interpretation: MB, ÖA, BÖ; Literature Review: MB, ÖA; Drafting/Writing: MB, ÖA; Critical Review: $\mathrm{MB}$, ÖA, BÖ.

\section{REFERENCES}

1. Kraus D, Peschel A. Staphylococcus aureus evasion of innate antimicrobial defense. Future Microbiol. 2008;3(4):437-51.

2. Verdú-Expósito C, Romanyk J, Cuadros-González J, TesfaMariam A, Copa-Patiño JL, Pérez-Serrano J, et al. Study of susceptibility to antibiotics and molecular characterization of high virulence Staphylococcus aureus strains isolated from a rural hospital in Ethiopia. PLoS One. 2020;15(3):e0230031.

3. Elsherif HM, Helal ZH, El-Ansary MR, Fahmy ZA, Eltayeb WN, Radwan S, et al. Staphylococcal enterotoxins and toxic shock syndrome toxin-1 and their association among bacteremic and infective endocarditis patients in Egypt. Biomed Res Int. 2020;2020:6981095.

4. Bachert C, Humbert M, Hanania NA, Zhang N, Holgate S, Buhl R, et al. Staphylococcus aureus and its IgE-inducing enterotoxins in asthma: current knowledge. Eur Respir J. 2020;55(4):1901592.

5. Suzuki Y, Ono HK, Shimojima Y, Kubota H, Kato R, Kakuda T, et al. A novel staphylococcal enterotoxin SE02 involved in a staphylococcal food poisoning outbreak that occurred in Tokyo in 2004. Food Microbiol. 2020;92:103588.

6. Alonzo F 3rd, Torres VJ. The bicomponent poreforming leukocidins of Staphylococcus aureus. Microbiol Mol Biol Rev. 2014;78(2):199-230.

7. Bukowski M, Wladyka B Dubin G. Exfoliative toxins of Staphylococcus aureus. Toxins (Basel). 2010;2(5):1148-65.

8. Oliveira D, Borges A, Simões M. Staphylococcus aureus toxins and their molecular activity in infectious diseases. Toxins (Basel). 2018;10(6):252.

9. Divyakolu S, Chikkala R, Ratnakar KS, Sritharan V. Hemolysins of Staphylococcus aureus-An update on their biology, role in pathogenesis and as targets for anti-virulence therapy. Adv Infect Dis. 2019;9(2):80104.

10. Thompson TA, Brown PD. Association between the agr locus and the presence of virulence genes and pathogenesis in Staphylococcus aureus using a Caenorhabditis elegans model. Int $\mathrm{J}$ Infect Dis. 2017;54:72-6. 
11. Bibalan MH, Shakeri F, Javid N, Ghaemi A, Ghaemi EA. Accessory gene regulator types of Staphylococcus aureus isolated in Gorgan, North of Iran. J Clin Diagn Res. 2014;8(4):DC07-9.

12. Tan L, Li SR, Jiang B, Hu XM, Li S. Therapeutic targeting of the Staphylococcus aureus accessory gene regulator (agr) system. Front Microbiol. 2018;9:55.

13. Jarraud S, Mougel C, Thioulouse J, Lina G, Meugnier H, Forey F, et al. Relationships between Staphylococcus aureus genetic background, virulence factors, agr groups (alleles), and human disease. Infect Immun. 2002;70(2):631-41.

14. Koneman EW, Allen SD, Janda WM, Schreckenberger PC, Winn WC, Washington MD. Staphylococci and related gram- positive cocci. In: Koneman's color atlas and textbook of diagnostic microbiology. 5th ed. USA: Lippincott Williams and Wilkins; 1997. p.539-65.

15. EUCAST. The European Committee on Antimicrobial Susceptibility Testing. Breakpoint tables for interpretation of MICs and zone diameters. Version 10.0, 2020:22-27.

16. Kim CH, Khan M, Morin DE, Hurley WL, Tripathy DN, Kehrli M Jr, et al. Optimization of the PCR for detection of Staphylococcus aureus nuc gene in bovine milk. J Dairy Sci. 2001;84(1):74-83.

17. Choi SM, Kim SH, Kim HJ, Lee DG, Choi JH, Yoo $\mathrm{JH}$, et al. Multiplex PCR for the detection of genes encoding aminoglycoside modifying enzymes and methicillin resistance among Staphylococcus species. J Korean Med Sci. 2003;18(5):631-6.

18. Omoe K, Hu DL, Takahashi-Omoe H, Nakane A, Shinagawa K. Comprehensive analysis of classical and newly described staphylococcal superantigenic toxin genes in Staphylococcus aureus isolates. FEMS Microbiol Lett. 2005;246(2):191-8.

19. Mehrotra M, Wang G, Johnson WM. Multiplex PCR for detection of genes for Staphylococcus aureus enterotoxins, exfoliative toxins, toxic shock syndrome toxin 1, and methicillin resistance. J Clin Microbiol. 2000;38(3):1032-5.

20. Lina G, Piémont Y, Godail-Gamot F, Bes M, Peter MO, Gauduchon V, et al. Involvement of PantonValentine leukocidin-producing Staphylococcus aureus in primary skin infections and pneumonia. Clin Infect Dis 1999;29(5):1128-32.

21. Gilot P, Lina G, Cochard T, Poutrel B. Analysis of the genetic variability of genes encoding the RNA IIIactivating components agr and TRAP in a population of Staphylococcus aureus strains isolated from cows with mastitis. J Clin Microbiol. 2002;40(11):4060-7.

22. Vasconcelos NG, da Cunha MLRS. Staphylococcal enterotoxins: Molecular aspects and detection methods. J Public Health Epidemiol. 2010;2(3):29-42.

23. Motamedifar M, Ebrahim-Saraie HS, Alfatemi SMH, Zalipour M, Kaveh M, Khoshkharam-Roodmajani H. Frequency of the toxic shock syndrome toxin-1 gene in methicillin-susceptible and -resistant Staphylococcus aureus isolates from teaching hospitals in Shiraz, Iran. Rev Soc Bras Med Trop. 2015;48(1):90-3.

24. Özel Y, Büyükzengin KB, Yavuz MT. Investigation of antibiotic resistance profile of methicillin resistant and susceptible Staphylococcus aureus strains isolated from clinical samples. ANKEM Derg. 2017;31(2):41-7.
25. Tanrıverdi Çaycı Y, Hasli F, Bilgin K, Birinci A. Evaluation of susceptibility of Staphylococcus aureus strains that isolated from blood cultures in Samsun Ondokuz Mayıs University Hospital between 20142017. KOU Sag Bil Derg. 2017;4(1):20-2.

26. Arıcı N, Aksaray S. Determination of meticillin resistance and investigation of antibiotic susceptibility of Staphylococcus aureus strains isolated from clinical samples. ANKEM Derg. 2019;33(2):70-6.

27. Duman Y, Kuzucu Ç, Çuğlan SS. Bacteria isolated from blood cultures and their antimicrobial susceptibility. Erciyes Med J. 2011;33(3):189-96.

28. Kılıç S, Beşirbellioğlu B, Kılıç A, Pasha A. Methicillin resistant Staphylococcus aureus infections determined at a training hospital in the years of 2003-2004. Gülhane Med J. 2005;47(3):195-8.

29. Şahin İ, Çalışkan E, Öztürk E, Yavuz MT, Türkmen Albayrak H, Karadağ G, et al. Distribution of microorganisms in blood culture and antimicrobial susceptiblity. Duzce Med J. 2013;15(2):11-4.

30. Karahan ZC, Tekeli A, Adaleti R, Koyuncu E, Dolapci I, Akan OA. Investigation of Panton-Valentine leukocidin genes and SCCmec types in clinical Staphylococcus aureus isolates from Turkey. Microb Drug Resist. 2008;14(3):203-10.

31. Gillet Y, Issartel B, Vanhems P, Fournet JC, Lina G, Bes M, et al. Association between Staphylococcus aureus strains carrying gene for Panton-Valentine leukocidin and highly lethal necrotising pneumonia in young immunocompetent patients. Lancet. 2002;359(9308):753-9.

32. Cirit OS, Yıldırım T, Çoban AY. Investigation of Panton-Valentine leukocidin presence in the clinical strains of Staphylococcus aureus. Balkan Med J. 2011;28(2):119-24.

33. Xie Y, He Y, Gehring A, Hu Y, Li Q, Tu SI, et al. Genotypes and toxin gene profiles of Staphylococcus aureus clinical isolates from China. PLoS One. 2011;6(12):e28276.

34. Jiménez JN, Ocampo AM, Vanegas JM, Rodríguez EA, Garcés CG, Patiño LA, et al. Characterisation of virulence genes in methicillin susceptible and resistant Staphylococcus aureus isolates from a paediatric population in a university hospital of Medellín, Colombia. Mem Inst Oswaldo Cruz. 2011;106(8):980-5.

35. de Souza CSM, Fortaleza CMCB, Witzel CL, Silveira M, Bonesso MF, Marques SA, et al. Toxigenic profile of methicillin-sensitive and resistant Staphylococcus aureus isolated from special groups. Ann Clin Microbiol Antimicrob. 2016;15:9.

36. Nhan TX, Leclercq R, Cattoir V. Prevalence of toxin genes in consecutive clinical isolates of Staphylococcus aureus and clinical impact. Eur J Clin Microbiol Infect Dis. 2011;30(6):719-25.

37. Demir C, Aslantaş Ö, Duran N, Ocak S, Özer B. Investigation of toxin genes in Staphylococcus aureus strains isolated in Mustafa Kemal University Hospital. Turk J Med Sci. 2011;41(2):343-52.

38. Hu DL, Omoe K, Inoue F, Kasai T, Yasujima M, Shinagawa $\mathrm{K}$, et al. Comparative prevalence of superantigenic toxin genes in meticillin-resistant and meticillin-susceptible Staphylococcus aureus isolates. J Med Microbiol. 2008;57(Pt 9):1106-12. 
39. Tekeli A, Koyuncu E, Dolapçı I, Akan OA, Karahan ZC. Molecular characteristics of methicillin-resistant Staphylococcus aureus strains isolated from blood cultures between 2002-2005 in Ankara University Hospital. Mikrobiyol Bul. 2009;43(1):1-10.

40. Kaneko J, Kamio Y. Bacterial two-component and hetero-heptameric pore-forming cytolytic toxins: structures, pore-forming mechanism, and organization of the genes. Biosci Biotechnol Biochem. 2004;68(5):981-1003.

41. Shukla SK, Karow ME, Brady JM, Stemper ME, Kislow J, Moore N, et al. Virulence genes and genotypic associations in nasal carriage, communityassociated methicillin-susceptible and methicillinresistant USA400 Staphylococcus aureus isolates. J Clin Microbiol. 2010;48(10):3582-92.

42. Aggarwal S, Jena S, Panda S, Sharma S, Dhawan B, Nath G, et al. Antibiotic susceptibility, virulence pattern, and typing of Staphylococcus aureus strains isolated from variety of infections in India. Front Microbiol. 2019;10:2763.

43. Li X, Fang F, Zhao J, Lou N, Li C, Huang T, et al. Molecular characteristics and virulence gene profiles of Staphylococcus aureus causing bloodstream infection. Braz J Infect Dis. 2018;22(6):487-94.

44. Arabestani MR, Rastiyani S, Alikhani MY, Mousavi SF. The relationship between prevalence of antibiotics resistance and virulence factors genes of MRSA and MSSA strains isolated from clinical samples, West Iran. Oman Med J. 2018;33(2):134-40.

45. Grumann D, Nübel U, Bröker BM. Staphylococcus aureus toxins--their functions and genetics. Infect Genet Evol. 2014;21:583-92.

46. Havaei S, Moghadam SO, Pourmand M, Faghri J. Prevalence of genes encoding bi-component leukocidins among clinical isolates of methicillin-resistant Staphylococcus aureus. Iran J Public Health. 2010;39(1):8-14.

47. He C, Xu S, Zhao H, Hu F, Xu X, Jin S, et al. Leukotoxin and pyrogenic toxin superantigen gene backgrounds in bloodstream and wound
Staphylococcus aureus isolates from eastern region of China. BMC Infect Dis. 2018;18(1):395.

48. Peerayeh SN, Azimian A, Nejad QB, Kashi M. Prevalence of $a g r$ specificity groups among Staphylococcus aureus isolates from university hospitals in Tehran. Lab Med. 2009;40(1):27-9.

49. Shopsin B, Mathema B, Alcabes P, Said-Salim B, Lina G, Matsuka A, et al. Prevalence of $a g r$ specificity groups among Staphylococcus aureus strains colonizing children and their guardians. J Clin Microbiol. 2003;41(1):456-9.

50. van Leeuwen W, van Nieuwenhuizen W, Gijzen C, Verbrugh H, van Belkum A. Population studies of methicillin-resistant and -sensitive Staphylococcus aureus strains reveal a lack of variability in the $\operatorname{agr} \mathrm{D}$ gene, encoding a staphylococcal autoinducer peptide. J Bacteriol. 2000;182(20): 5721-9.

51. Manago K, Nishi J, Wakimoto N, Miyanohara H, Sarantuya J, Tokuda K, et al. Biofilm formation by and accessory gene regulator typing of methicillin-resistant Staphylococcus aureus strains recovered from patients with nosocomial infections. Infect Control Hosp Epidemiol. 2006;27(2):188-90.

52. Sakoulas G, Eliopoulos GM, Moellering RC Jr, Wennersten C, Venkataraman L, Novick RP, et al. Accessory gene regulator (agr) locus in geographically diverse Staphylococcus aureus isolates with reduced susceptibility to vancomycin. Antimicrob Agents Chemother. 2002;46(5):1492-502.

53. Yoon HJ, Choi JY, Lee K, Yong D, Kim JM, Song YG. Accessory gene regulator group polymorphisms in methicillin-resistant Staphylococcus aureus: an association with clinical significance. Yonsei Med J. 2007;48(2):176-83.

54. Ji G, Beavis R, Novick RP. Bacterial interference caused by autoinducing peptide variants. Science. 1997;276(5321):2027-30.

55. Fisher EL, Otto M, Cheung GYC. Basis of virulence in enterotoxin-mediated staphylococcal food poisoning. Front Microbiol. 2018;9:436. 